\title{
Magnetic and Electricalprospections in the Archaeological Site of Xalasco, Northeast of Tlaxcala, Mexico
}

\author{
Karla R Juárez ${ }^{1}$, Pedro A López-García ${ }^{2}$, Denisse L Argote-Espino ${ }^{3 *}$, Andrés Tejero-Andrade ${ }^{1}$, René E Chávez ${ }^{4}$ \\ and Alejandro García-Serrano ${ }^{1}$
}

${ }^{1}$ Department of Earth Sciences, National Autonomous University of Mexico Circuito Escolar, Mexico

${ }^{2}$ Department of Archeology and History, National Institute of Anthropology and History, Mexico

${ }^{3}$ Department of Archaeological Studies, National Institute of Anthropology and History, Mexico

${ }^{4}$ Department of Geomagnetism and Exploration, National Autonomous University of Mexico, Mexico

Submission: September 15, 2017; Published: October 17, 2017

*Corresponding author: Denisse L Argote-Espino, Directorate of Archaeological Studies, National Institute of Anthropology and History, Lic. Primo Truth no. 2, Col. Centro, Deleg. Cuauhtémoc, Mexico City, Email: efenfi@gmail.com

\begin{abstract}
Magnetic and electrical surveys were implemented in the archaeological site of Xalasco, in the state of Tlaxcala, Mexico, in order to detect archaeological structures of interest, as well as to characterize the subsoil. The analysis of the information obtained by measuring physical properties of the subsoil allowed us to identify and understand the distribution of underground features like walls, floors and platforms, aiding in the determination of potential excavation areas. The results are presented after correcting and processing the acquired data. By applying different operators to the magnetic data, primarily the analytic signal operator, more information was acquired for the identification of the buried structures. Complementing these results through a three-dimensional inversion of Electrical Resistivity Tomography, the depth of a pre-Hispanic road was estimated. The common capabilities that exist between the magnetic and electrical surveys helped us to compare, complement and link the information provided by each method, correlating the final outcome with the results of the archaeological excavations in selected areas of interest.
\end{abstract}

Keywords: Magnetometry; Electric resistivity tomography; Archaeological prospecting; Xalasco; Tlaxcala; Mexico

\section{Introduction}

Tlaxcala was one of the most populated regions of Mesoamerica in pre-Hispanic times; almost one thousand archeological sites have been recorded in its small territory, inhabited at different times during the last three millennia [1]. Tlaxcala remained for along time at the forefront of Mesoamerican cultural development, having fertile soils of volcanic origin but with a climate that presents certain disadvantages for the cultivation of maize, mainly the unexpected rains and the threat of resisting the frost season. These could be one of the reasons why the first farming villages in the area emerged after $1000 \mathrm{BC}$. Throughout the Preclassic period (1000BC-100AD), hundreds of villages appeared and disappeared; many settlements suffer total abandonment, perhaps because several of its inhabitants migrated to the emerging metropolis of Teotihuacan or other early cities [2]. Nowadays, this great cultural heritage is disappearing under a growing urban spot.

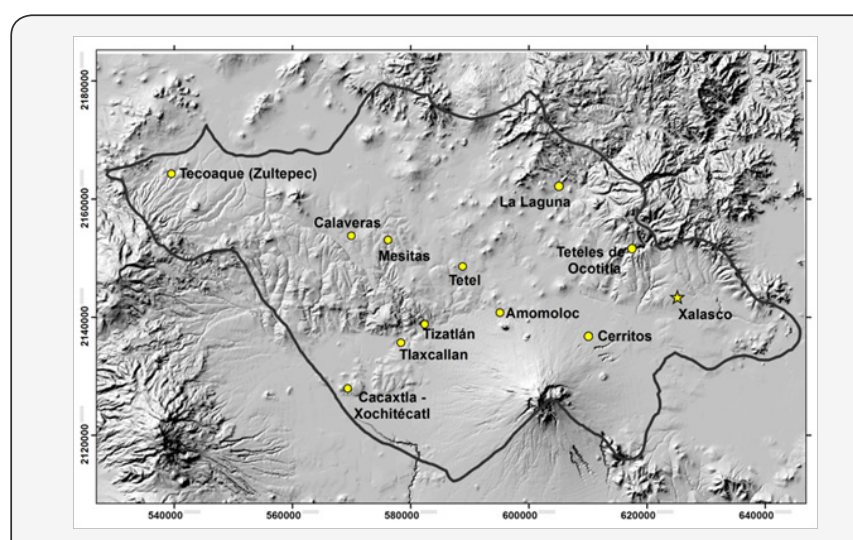

Figure 1: Location map of some important archaeological sites investigated in the state of Tlaxcala, including Xalasco.

Researchers from the National Institute of Anthropology and History (INAH) of Mexico have devoted time and efforts to 
investigate number of areas in the state of Tlaxcala (Figure 1), due to its history and the findings belonging to ancient times. In the 1970's, several archaeological studies were carried out, coordinated by Mexican archaeologists Ángel García Cook and Leonor Merino Carrión and supported by the German Foundation for Scientific Research-F.A.I.C. [3,4]. Other archaeological salvage projects were carried in the area of Xalasco in 2006, 2008 and 2010 [5-7]. In addition, other projects in the sites of Teteles de Ocotitla and Xalasco have been performed since 2006 [8-11]. The present paper deals with recent archaeological and geophysical studies carried out in the pre-Hispanic site of Xalasco.

The archaeological site of Xalasco was occupied in the Classic period (200-700AD.), and was the seat of multiethnic groups of elite, artisans and/or emissaries of Teotihuacan or people who shared Teotihuacan cultural baggage. The presence of at least two cultures was observed in the materials proceeding from Xalasco: a local one called Tenayecac and another with clear Teotihuacan influences, as well as Veracruz and southern Puebla [7]. This settlement, located on a plateau in the northeast portion of Tlaxcala state, is geographically situated within the routes that communicated the coast of the Gulf of Mexico and the ancient metropolis of Teotihuacan, so probably this area functioned as a center of exchange and/or redistribution of products with some type of productive specialization [5].

García Cook [4] proposed the existence of sites in Tlaxcala within the Teotihuacan corridors, which allowed traders to establish bases between their trips to the Gulf of Mexico coast and back. This theory is based on the types of archaeological materials found in the area, some of them now deposited in the local community museum of Atltzayanca. The characteristics of the archaeological materials show a constant and dynamic interaction between different areas to the east of the plateau, so it can be thought that this settlement, along with other sites in the Tlaxcala valley, had an important role in the sustainment and development of the great city of Teotihuacan by allowing the passage of resources that came from the Gulf as well as from southeastern Mexico and the south of Puebla. Xalasco was a locality for exchange and transport of raw materials and products between these regions [7].

The main objective of this research was to detect archaeological structures through the implementation of magnetic and electrical surveys in the archaeological site of Xalasco, Tlaxcala, Mexico, in order to acquire information about their location and depth. In general, geophysical methods measure different physical properties of the materials that compose the subsoil of the area of interest. The measured properties not only depend on geological processes, but also reflect the different alterations produced by the anthropogenic activity over time. The analysis of the information obtained through the application of geophysical methods allowed us to locate, identify and understand the distribution of underground features like walls, floors, voids and platforms, aiding in the determination of potential excavation areas. The results of the geophysical study carried out on the archaeological site, as well as their verification through archaeological excavations, are shown in this work.

\section{Regional setting}

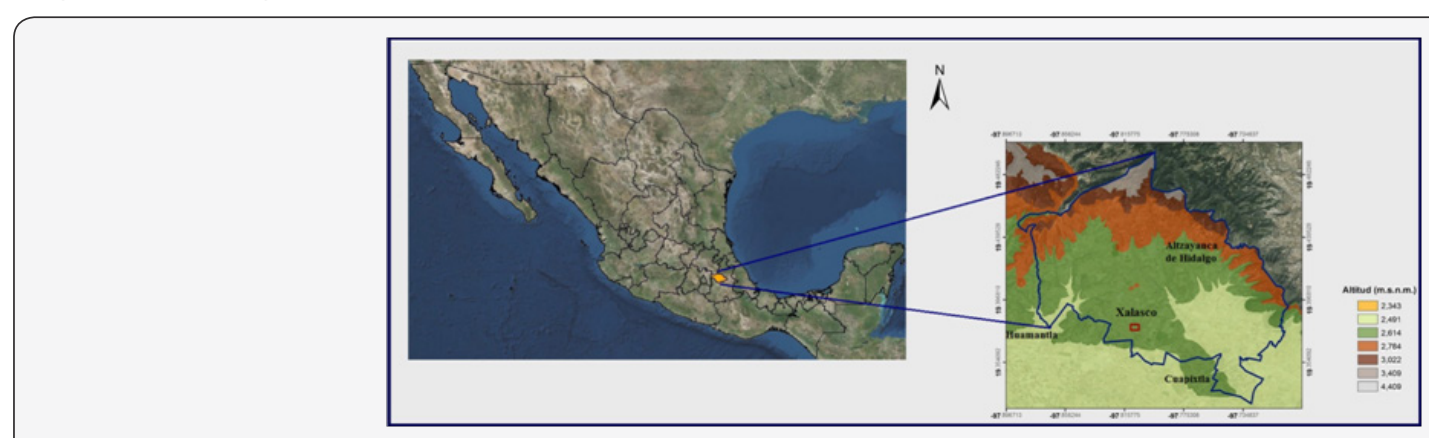

Figure 2: Location of Xalasco archaeological site.

The state of Tlaxcala, located in Central Mexico highlands, is the smallest state in the national territory, with an extension of $3,997 \mathrm{~km}^{2}$. It borders to the north, east and south with the state of Puebla, to the northwest with the state of Hidalgo and to the west with the state of Mexico. From a physiographic point of view, it is located at the junction of the Sierra Madre Oriental with the transverse volcanic system. The archaeological site of Xalasco (Figure 2) is located in the municipality of Atltzayanca. It lies between the parallels $19^{\circ} 19^{\prime}$ and $19^{\circ} 30^{\prime}$ north and the meridians $97^{\circ} 42^{\prime}$ and $97^{\circ} 53^{\prime}$ west, with altitudes ranging between 2400 and 4400 m.a.s.l. Atltzayanca borders to the north with the municipality of Terrenate and the state of Puebla, to the east with the state of Puebla and the municipalities of El Carmen Tequexquitla and Cuapiaxtla, to the south with the municipality of Cuapiaxtla, and to the west with the municipalities of Cuapiaxtla, Huamantla and Terrenate.

The local geology of the municipality of Atltzayanca (Figure 3) belongs to the Quaternary (79\%) and Neogeneperiods (18\%), being the rocks that compose it of the following types:

a. Volcanic rocks: andesites $=18 \%$, acidic tuffs $=50 \%$;

b. Sedimentary: sedimentary gap $=26 \%$, alluvial soils $=3 \%$. 

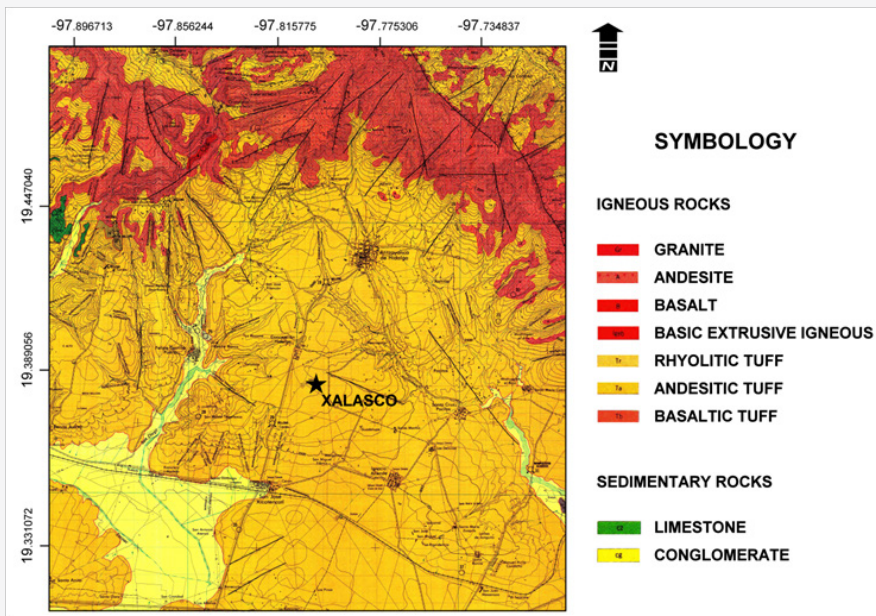

Figure 3: Geological chart of Atltzayanca and Huamantla regions, Tlaxcala (code E14B34; scale 1:50,000; Source: INEGI, 2009). The location of Xalasco is marked.

The flat and lower parts of the municipality of Atltzayanca are composed of tuffs and ashes, derived from the volcanic activity of La Malinchevolcano in the Lower Pliocene, which are interrupted to the south by the presence of fluvial sediments. The pedology of the area of Xalasco is characterized by poor, sandy, light-gray or yellowish soils. These soils originated from tuffs and other pyroclastic materials, which are fragmented volcanic materials constituted of a large variety of sizes, colors, minerals and deposit forms. Pumice fragments of acid and intermediate composition, andesite, trachyte and some basalt may also be found.

\section{Material and Methods}

\section{Magneto metric prospection}

Magnetometry aims to detect local variations in the intensity of the Earth's magnetic field, also called "magnetic anomalies". For this reason, the instruments for conducting magneto metric prospections are based on the fundamental natural properties of the Earth. The application of this potential method in Archaeology is directed towards the detection of magnetic anomalies of anthropic origin. These alterations are the result of two different magnetic phenomena [12].

Induced magnetism: The materials present in the subsoil have different capabilities of being magnetized by the local magnetic field (magnetic susceptibility), mainly due to the amount of the ferromagnetic elements they contain.

Remnant thermo-magnetization: It is one of the most well-known magnetic phenomena and one of the first studied in archeology. Kilns, pottery and burned floors are usually made of clay which contain, in a greater or lesser extent, iron-oxide particles that upon heating converts to magnetite $\left(578^{\circ} \mathrm{C}\right)$ or maghaemite $\left(578^{\circ} \mathrm{C}-675^{\circ} \mathrm{C}\right)$. Both minerals, with a high degree of magnetization, can be registered by a magnetometer, observing a strong contrast of them with respect to the magnetic field of its immediate surroundings. The remnant magnetism is a product of the composition of an object and its thermal, depositional and digenetic history.

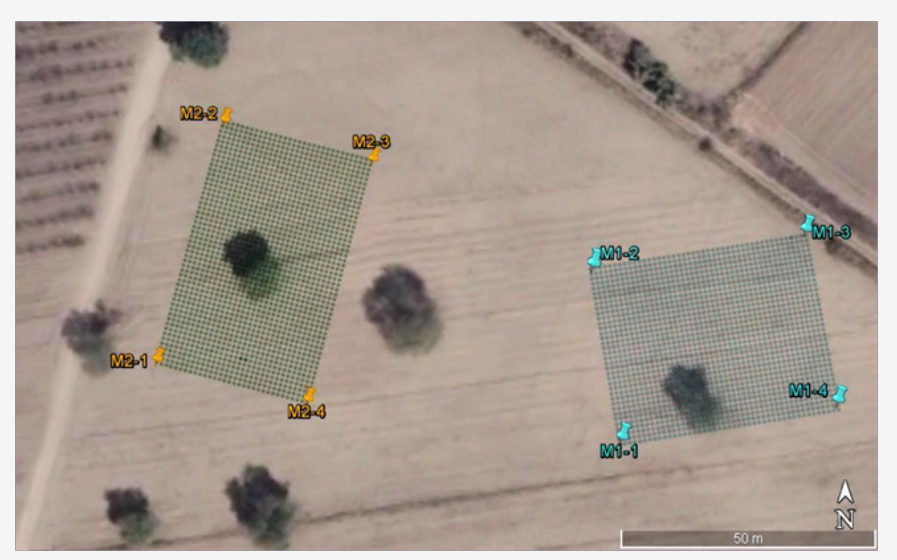

Figure 4: Location of the two meshes (M1 and M2) prospected with magnetometry in the site of Xalasco. 
During the magnetometric study in the site of Xalasco, two areas were selected to be surveyed. Such spaces possessed archaeological potential, according to previous reports of investigations carried out in the surrounding areas [6-7] and the great amount of surface materials. Total Field and Vertical Gradient observations were acquired from both areas with the purpose of obtaining a series of magnetic measurements. Figure 4 depict the location of the investigated areas; the blue marks belong to the first mesh, denominated $\mathrm{M}_{1}$, and the orange marks belong to the second mesh, denominated $\mathrm{M}_{2}$. The meshes covered an area of $44 \mathrm{~m} \times 35 \mathrm{~m}$ (for $\mathrm{M}_{1}$ ) and of $31 \mathrm{~m} \mathrm{x} 50 \mathrm{~m}$ (for $\mathrm{M}_{2}$ ), and were separated approximately $50 \mathrm{~m}$ from each other.

The equipment used for the prospection was a Cesium magnetometer (G-858 model) with a resolution of $0.0015 \mathrm{nT}$. The exact position of the lectures was attained through a GPS module adapted to the magnetometer. A second magnetometer, which served as a fixed base station, was installed in the surrounding area in order to correct the diurnal variations of the primary magnetic field. The data processing was carried out using Oasis Montaj Software (C) 2013 Geosoft Inc.). It is important to mention that preliminary results obtained with the magnetic method were employed to select the area for the threedimensional Electrical Resistivity Tomography. The objective was to correlate zones with relevant magnetic anomalies with the electrical study.

\section{Processing and creation of maps}

After correcting the data for diurnal variation, the original space-domain signal was transformed into the wave-domain in order to apply suitable digital filters for obtaining a more revealing output signal, in terms of interpretation and analysis of the collected information. The analysis applied to the corrected magnetic data consisted of several types of treatments based on mathematical algorithms, making possible to remove noise and sections of the original signal that were not essential. As a result of this type of process, a "noise-free" total magnetic field anomaly could be recognized [13]. The maps in the following sections are the result of the processing performed and applied to the data of the magnetometric study.

\section{Analytical Signal}

The Analytical Signal method was first applied by Nabighian [14] in magnetic data profiles. The importance of this method is that it is theoretically independent of the Earth's magnetic field and the magnetization vector, presenting it in the form of an acute bell where the maximum is located directly on the edges of the bodies that cause the anomalies, in addition to being proportional to their depth of burial. This process allows restricting the depth and dimensions of the causal sources.

The 3D Analytical Signal of the anomaly of a potential field can be denoted as:

$$
\mathrm{A}(x, y)=\left[\frac{\partial \phi}{\partial x} \hat{x}+\frac{\partial \phi}{\partial y} \hat{y}+\frac{\partial \phi}{\partial z} \hat{z}\right]
$$

Where, and are the unitary vectors in $\mathrm{X}, \mathrm{Y}$ and $\mathrm{Z}$, respectively. The greatest advantage obtained by applying the analytical signal process is that the result is exempt from the effects of the inclination of the earth's magnetic field, thus showing the location of the limits of the bodies or sources that produce the magnetic anomalies.

The amplitude of the $3 \mathrm{D}$ analytical signal at a position $(\mathrm{x}, \mathrm{y})$ on a magnetic contact is a symmetrical bell-shaped function, where each maximum occurs at the boundaries of the magnetized body and from which it can be derived the three orthogonal gradients of the total magnetic field with the following expression:

$$
|A(x, y)|=\sqrt{\left(\frac{\partial \phi}{\partial x}\right)^{2}+\left(\frac{\partial \phi}{\partial y}\right)^{2}+\left(\frac{\partial \phi}{\partial z}\right)^{2}}
$$

Where $|\mathrm{A}(x, y)|$ it is the amplitude of the analytical signal in $(\mathrm{x}, \mathrm{y})$ and $\phi$ is the observed magnetic field.

\section{Electrical survey}

A three-dimensional Electrical Resistivity Tomography (3D-ERT) was implemented to obtain information regarding the variations of the apparent resistivity of the materials in the subsoil. ERT is a method that allows investigating the variation in the resistivity of the soil, laterally and in depth, performing measurements over the surface of the ground [15]. ERT (2D and 3D) methods are based on modeling the resistivity values of the subsoil by applying numerical techniques. With the observed resistivities, a two-dimensional section or a threedimensional model is created, depending on the technique used [15]. Subsequently, an inversion method is applied to the data to generate a mathematical model representative of the resistivity values measured on the field [16]. The final resistivity model can be visualized as an image of a geoelectric profile or a threedimensional representation, picturing the relationship between the physical properties of the materials that characterize the subsoil.

In Xalasco, an area of $15 \mathrm{mx} 47 \mathrm{~m}$, located within mesh 1 $\left(\mathrm{M}_{1}\right)$ of the magnetic survey, was chosen to perform the 3D-ERT survey (Figure 5). Four parallel profiles of $47 \mathrm{~m}$ of length running approximately in a north-south direction were deployed, with a separation of $5 \mathrm{~m}$ between profiles and $2 \mathrm{~m}$ between electrodes. The depth of investigation reached $6.7 \mathrm{~m}$. The equipment used was a SyscalPro48 with a switch box which allowed the employment of 48 additional electrodes, making possible to collect data from two profiles simultaneously. Copper electrodes with a $3 / 4$-inch diameter and $0.30 \mathrm{~m}$ in length were utilized, hydrated with a solution of copper sulfate $\left(\mathrm{CuSO}_{4}\right)$. The software used for numerical data processing was Earth Imager 3D.

A combination of a Wenner-Schlumberger array (W-S) and an Equatorial array (Eq) was proposed for this investigation [16-19]. The W-S array was conducted in each of the physical lines and the Eq array was applied between parallel lines. The combination of both arrays was chosen for their high sensitivity 
to lateral and vertical changes in resistivity and because they present a high signal/noise ratio [20]. Data collected with these arrays allowed us to carry out a three-dimensional investigation of the distribution of the resistivity in the subsoil.

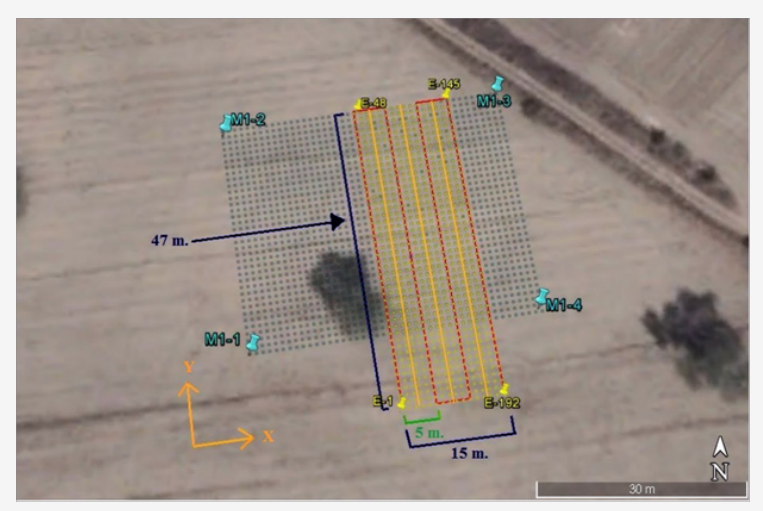

Figure 5: ERT survey coincident with the magnetometric study (grid M1): the red lines represent the four ERT profiles performed with a WennerSchlumberger array; the orange lines indicate the location of the three profiles performed with the Equatorial array.

\section{Results and Discussion}

\section{Total magnetic field maps}

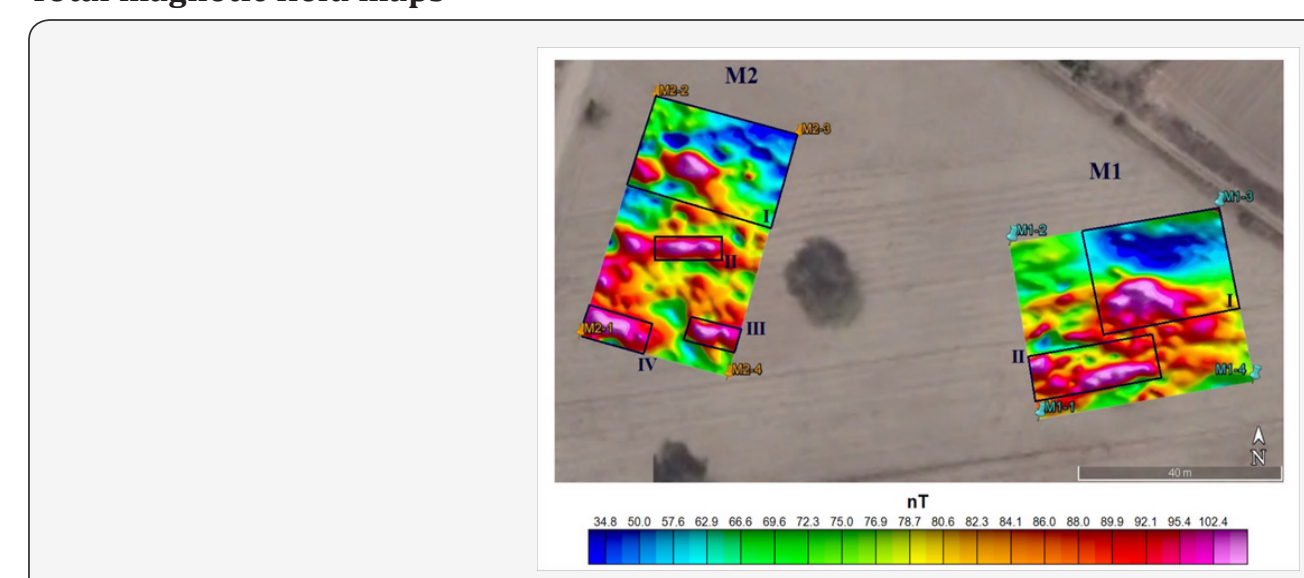

Figure 6: Total-field magnetic anomalies map of grids M1 and M2.

Total Magnetic Field surveys were carried out over the surface of the terrain of the areas of interest to detect anomalies with high magnetic values related to bury structures of archaeological importance. To produce the magnetic anomaly map, collected data was corrected by taking into account the diurnal variation and the latitude effect [21]. In Figure 6 are presented the Total Field maps of both meshes showing the principal magnetic anomalies. The most remarkable anomalous contrasts are delimited by rectangles. $\mathrm{M}_{1}$ and $\mathrm{M}_{2}$ maps display several dipolar anomalies. The anomalies corresponding to the strongest contrasts between magnetic values are located in rectangles I of both maps, while the rectangles marked as II (in $\mathrm{M}_{1}$ and $\mathrm{M}_{2}$ ), III and IV (only in $\mathrm{M}_{2}$ ) include elongated anomalies with high magnetic values (between 50.55 and 69.59nT). Visually comparing the anomalies, the high magnetic anomaly inside rectangle $I$ of $M_{1}$ is the largest in size. Its area and high magnetic values pointed out the possibility of finding an archaeological structure of important dimensions.
This hypothesis was also supported by the structures found during the archaeological excavations performed in an area located $50 \mathrm{~m}$ to the northeast of $\mathrm{M}_{1}$ [20]. Other important anomalies were registered in several sections of the map, surely belonging to smaller structures located in the area of study. M2 map also presents dipolar anomalies aligned in a NE-SW direction.

\section{Analytical signal maps}

The anomalies observed in the analytical signal maps (Figure 7), delimited by rectangles, and were better defined than in the Total Magnetic Field maps. The contribution of the applied process to the residual anomalies was of great importance in the characterization of zones with archaeological potential. In the Analytical Signal map of $M_{1}$, within the area delimited by rectangle I-II, can be clearly distinguished an elongated anomaly (with magnetic values>8.0nT) than the one suggested by the Total Field map, which could indicate the presence of a larger structure, like a buried floor or platform. 


\section{Global Journal of Archaeology \& Anthropology}

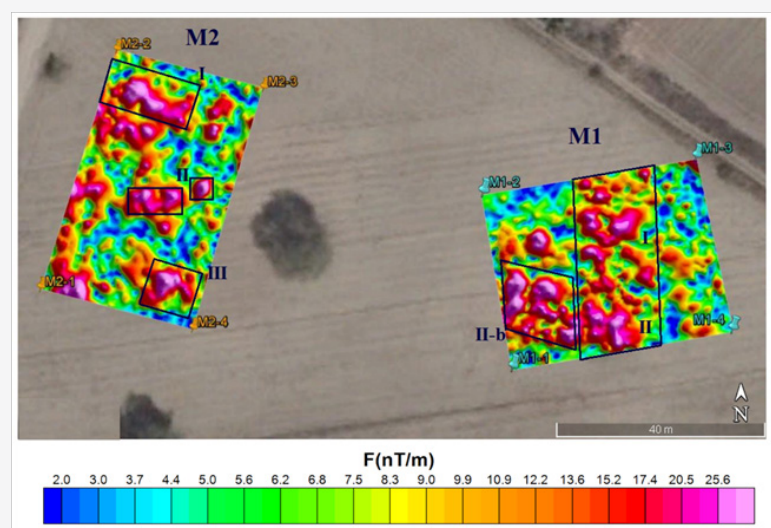

Figure 7: Analytical Signal maps from the studied areas.

In $\mathrm{M}_{2}$ map, the sections delimited by rectangles II and III enclose high magnetic value anomalies (ranging from 8 to $21.7 \mathrm{nT} / \mathrm{m}$ ) surrounded by contrasting low magnetic values (from 1.54 to $3.05 \mathrm{nT} / \mathrm{m}$ ). These sections were of interest since the geometries formed by the contrasts between the magnetic values could provide evidence of buried structures. By visualizing and correlating section (II-b) of M1 map with section III of $\mathrm{M}_{2}$ map, it is observed that both anomalies have similar tendencies (orientated in a NW direction) and values ranging from 12 to $22.89 \mathrm{nT} / \mathrm{m}$, suggesting associated features. Therefore, it is recommended to carry out a future magneto metric study in the area between both sections, which could provide us more information about the distribution of the archaeological structures in this portion. Due to time and financial issues, this could not be accomplished in this phase of the study.

\section{Magnetic vertical gradient maps}

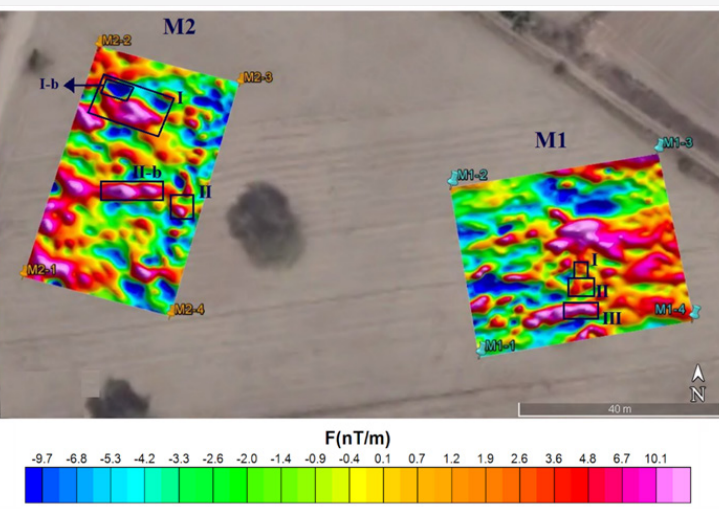

Figure 8: Magnetic vertical gradient maps. Relevant anomalies are marked with rectangles.

To obtain the Vertical Gradient map, the magnetic data were filtered in order to eliminate noise. Furthermore, a low pass filter was applied in addition to a directional cosine filter. This process helped to perform a better analysis and an adequate interpretation of the results obtained from the study. In Figure 8, some relevant anomalies are delimited by rectangles. This map displays dipolar anomalies with vertical gradient values ranging from -6 to $16 \mathrm{nT} / \mathrm{m}$, aligned in a NE-SW direction. These could be related to the magnetization contrasts between possible magnetic archaeological features and the surrounding soil [22].

Archaeological excavations were planned in the areas marked by rectangles I and II in order to verify the source of the anomalies in $\mathrm{M}_{2}$. The anomaly present in rectangle $\mathrm{I}$, at the top left corner of $\mathrm{M}_{2}$ map with high magnetic values ranging from 6.46 to $13 \mathrm{nT} / \mathrm{m}$, corresponded to a compact wall made of thin andesitic stone slabs surrounded by a floor, also composed of stone slabs (Figure 9), that can be interpreted as part of a highrank habitation or administrative complex. A visual analysis of the magnetic anomaly displayed in rectangle I-b of M2 map (Figure 8) indicates the presence of remnant magnetic effects, since the anomaly is not oriented in the direction of the Earth's magnetic field [23]. During the excavation process in this section, burned charcoal and several pieces of phalanges belonging to human skeletons were found at a depth of $60 \mathrm{~cm}$ (Figure 10).

In rectangle II of M2 map (Figure 8), an anomaly with high magnetic values ranging from 10 to $15.86 \mathrm{nT} / \mathrm{m}$ is outlined. This anomaly corresponded to the first two steps of a stairway made of compact andesitic stone slabs placed over a platform covered by a floor of thin large polished stone slabs (Figure 11). The floor of the platform was encountered at a depth of $80 \mathrm{~cm}$. 


\section{Global Journal of Archaeology \& Anthropology}

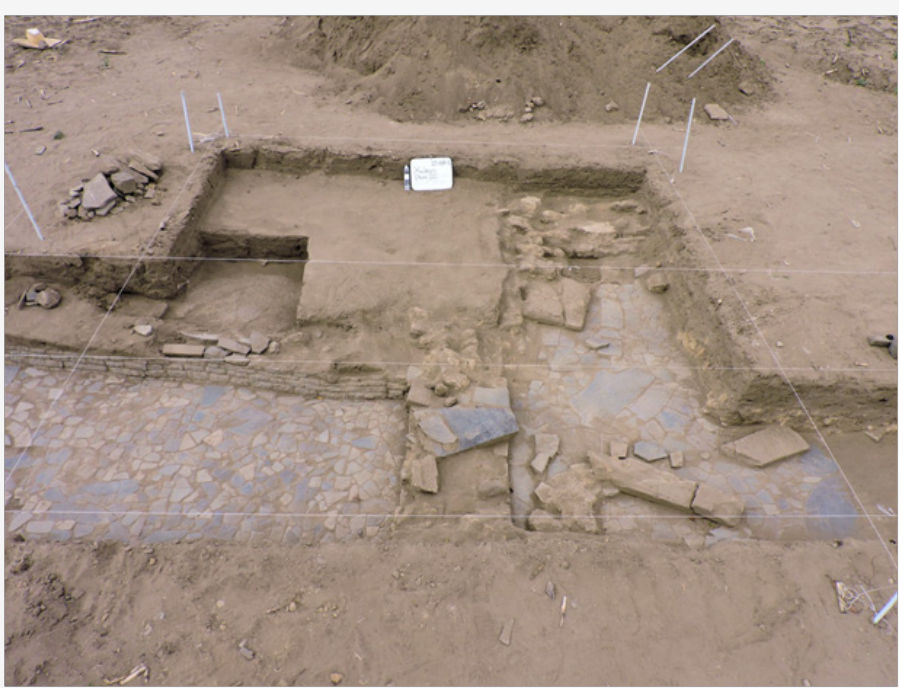

Figure 9: Stone-slabs floor and wall registered during the excavation of M2.

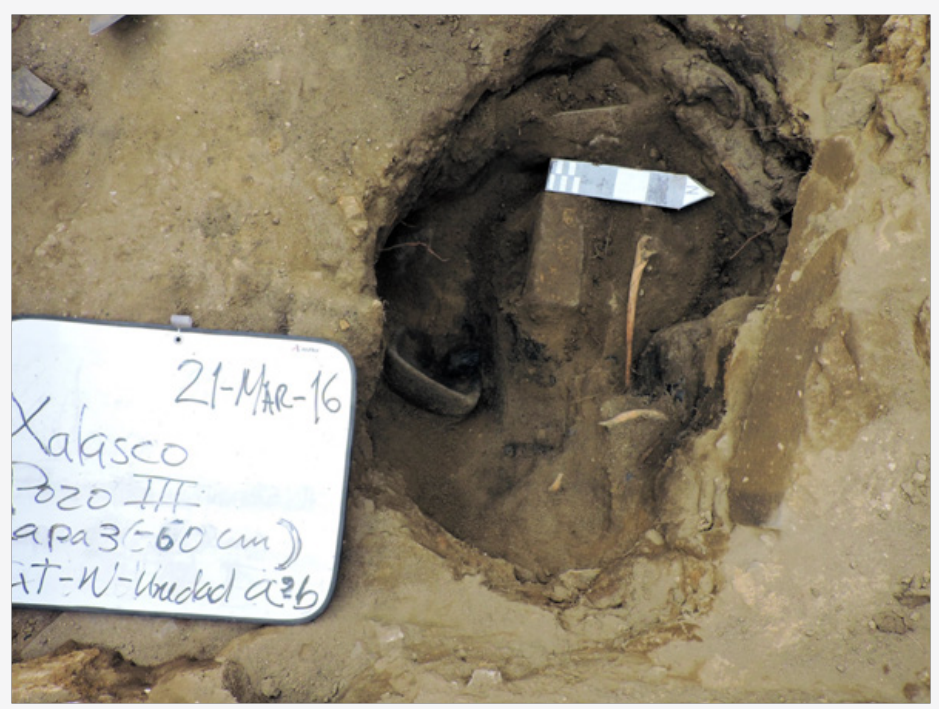

Figure 10: Burned charcoal and several pieces of phalanges belonging to human skeletons found during the excavation.

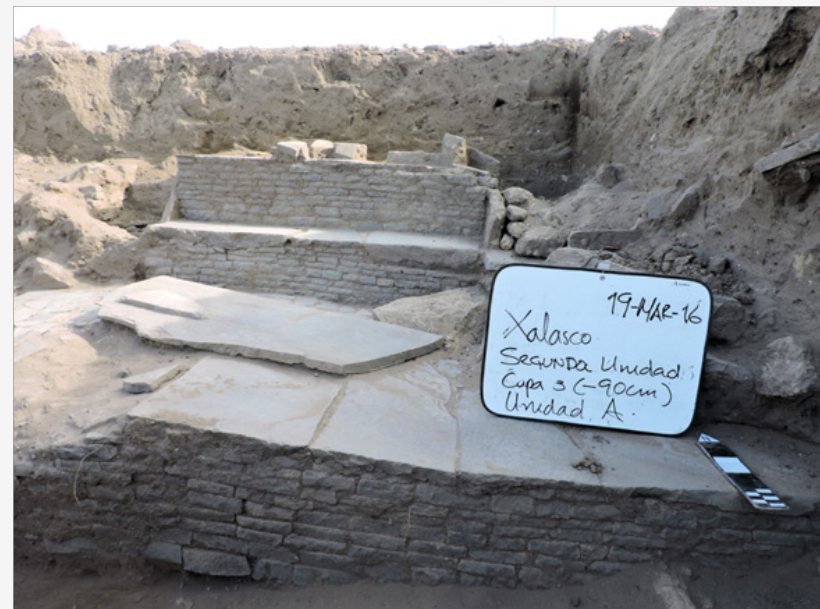

Figure 11: Steps of a stairway made of compact andesitic stone slabs placed over a platform covered by a floor of thin large polished stone slabs, found in excavation of rectangle II of M2 


\section{Global Journal of Archaeology \& Anthropology}

\section{D-ERT images}

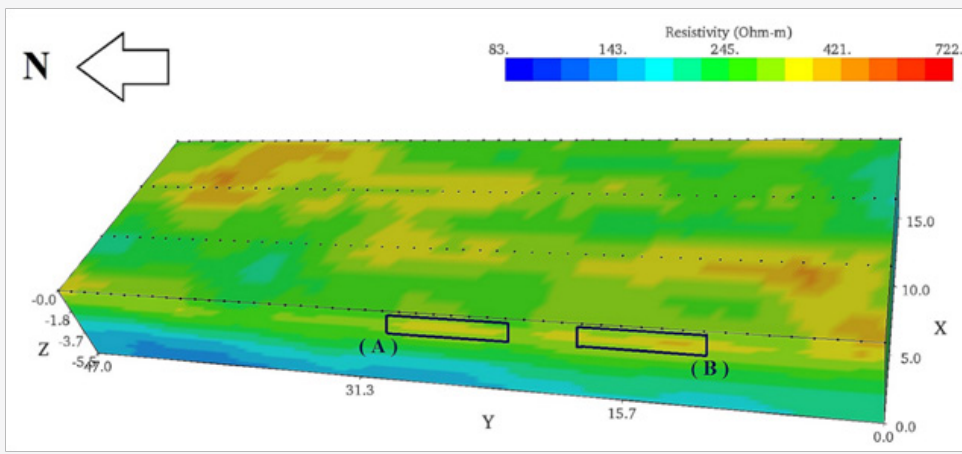

Figure 12: Side view of the inverted model obtained from the ERT data in Xalasco. The model shows the distribution of resistivities in the subsoil. The rectangles $A$ and $B$ delimit the depth of the anomalies with high resistivity values that were analyzed and correlated with the structures found during the excavations.

By means of the 3D-ERT inverted model (Figure 12), it was possible to visualize the presence of interesting electrical anomalies, whose pattern scold be compared with the information provided by the magnetic method. This image shows a sort of platform that runs from north to south, approximately, towards the main ceremonial center of the site [24]. This feature has an average depth of $1 \mathrm{~m}$ beneath the surface. Its width (E$\mathrm{W}$ ) is approximately $7 \mathrm{~m}$ and its total length (N-S) cannot be specified as it runs along the entire electrical image. There are signs of being partially destroyed.
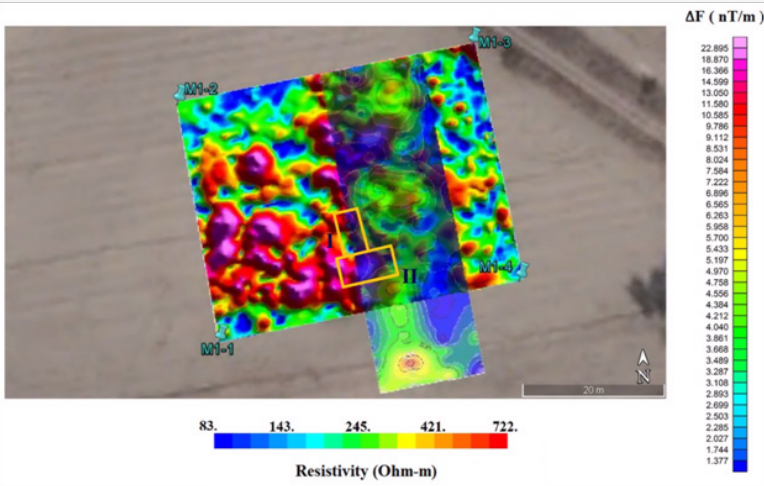

Figure 13: Superposition of the Analytical Signal map and a horizontal section taken from the 3D-ERT inversion model. High magnetic values coincide with high resistivity values of the ERT model. Rectangles I and II were excavated.

By superposing the analytical signal map with the ERT model (Figure 13), it is possible to observe the coincidence of higher resistivity values ( $>400 \mathrm{ohms}-\mathrm{m})$ with the high magnetic values of M1, detecting the same feature in a matching position. In addition, the magnetic map registered several minor anomalies distributed in the upper left quadrant (northwest of the mesh), which could correspond to rooms or habitation units. Based on the results obtained in the geophysical surveys, where the presence of possible architectural structures at relatively shallow depths was evidenced, an excavation was realized in the rectangles marked as I and II in Figure 13.

During the excavations executed in this portion, a large floor made of compacted dirt and cooked clay was found at a depth of $80 \mathrm{~cm}$, limited by stone blocks and stone slab walls in the western flank (Figure 14). The floor was around $8 \mathrm{~m}$ width and had an N-S orientation towards the highest mound of the site; however, its total extension could not be determined. This floor can be inferred as part of a road that gave access to the main ceremonial center of the settlement. Unfortunately, it was destroyed in several parts due to modern agricultural activities [25].

With the results obtained in this research, it is possible to emphasize that the information provided by the magneto metric prospection was complemented by the ERT survey, demonstrating that the combination of both geophysical methods applied in archeological exploration provide satisfactory results, which lead to successful excavations.

\section{Conclusion}

Geophysical methods have turned out to be efficient and fast tools in the exploration of an archaeological site, representing non-invasive and non-destructive means for inferring the internal complexity of buried features of archaeological interest [26]. Therefore, their application is suitable in order to plan 
systematic excavations based on the construction of maps and 3D models of individual anomalies, providing a high-success rate. Another benefit is the reduction of time and cost invested in the research. The use of geophysical methods depends entirely on the objective to be investigated and on the characteristics of the environment, in which a study of the subsoil is requested. In this research, the magnetic and electrical methods provided an optimal visualization of the information of the subsoil in the archaeological site of Xalasco, delimitating potential areas to perform systematic excavations according to the position of the anomalies, dimensions and minimum and maximum depth. The excavations revealed important pre-Hispanic features like walls, staircases and floors. The ERT method resolved the location of archaeological structures like roadways and walls, while the magnetometric method allowed us to identify many other potential targets (including collapsed structures). The verification of the anomalies through archaeological excavations supplied new insights about the internal variability of the site, registering in M1 the presence of a possible roadway that gave access to the main ceremonial area, surrounded by high-rank habitation or administrative units. The depth estimated by the ERT model coincided with the depth to which these structures were found. In M2, we were able to identified also high-rank habitation or civic units conformed by walls and floors made of fine-worked andesitic stone slabs. The overall results indicate us a relevant use of the space in this area, highly linked to the main ceremonial center and where administrative or ceremonial activities were carried out.



Figure 14: Large floor made of compacted dirt and clay, limited by stone blocks and stone-slab walls in the western flank, found during the excavations of $\mathrm{M}_{1}$.

\section{Acknowledgment}

We would like to thanks and ra Esteves Robles and Pablo Aguirre Díaz for all their priceless support in the geophysical data collection. We also would like to thank Oscar Guillermo Huacuja Montielin the execution of the archaeological excavations. This research was supported by the CONACYT [project CB2011/168476].

\section{References}

1. Carballo A (2016) Del Preclásico al Epiclásico en Tlaxcala. Arqueología Mexicana 24(139): 32-41.

2. Borejsza A (2016) Tlaxcala en la época prehispánica. Arqueología Mexicana 139: 26-31.

3. García Cook A, Merino B (1996) Antología de Tlaxcala I. Colección Antologías, INAH, Mexico.

4. García Cook A, Merino B (Comps.) (1997) Antología de Tlaxcala II, III and IV. Colección Antologías, INAH, Mexico.

5. Bautista JA (2006) Interacción cultural en el oriente de Tlaxcala durante el Clásico. El caso de Xalasco, Municipio de Atlzayanca. Unpublished dissertation, Escuela Nacional de Antropología e Historia, México.

6. Bautista JA (2008) Informe técnico del Proyecto Xalasco. Proyecto de excavación en el sitio arqueológico de Xalasco, municipio de Altzayanca, Tlaxcala. Unpublished report, INAH, México.
7. Manzanilla LR, Aguayo E, Hernández M, Bautista A (2011) Informe técnico final del salvamento de un conjunto con materiales teotihuacanos en Xalasco, Atltzayanca, Tlaxcala 2008. Unpublished report, INAH, México.

8. Argote-Espino D, Tejero A, Chávez RE, López PA, Bravo R (2009) 3D modeling of magnetic data from an archaeological site in northwestern Tlaxcala state, Mexico. Journal of Archaeological Science 36(8): 1661-1671.

9. Argote-Espino DL, López-García P, Tejero-Andrade A (2016) 3D-ERT geophysical prospecting for the investigation of two terraces of an archaeological site northeast of Tlaxcala state, Mexico. Journal of Archaeological Science: Reports (8): 406-415.

10. López García PA (2007) Informe de los estudios de área y patrón de asentamiento en la región oriental de Huamantla. Problemas de investigación y conservación. Unpublished report, INAH, México.

11. López-García P, Argote-Espino DL, Tejero-Andrade A, Chávez-Segura R (2014) Integral geophysical study to characterize archaeological structures in Los Teteles de Ocotilta, Mexico. Open Journal of Archaeometry 2(1): 77-80.

12. Scollar I, Tabbagh A, Hesse A, Herzog I (1990) Archaeological prospecting and remote sensing. Cambridge University Press, Cambridge, USA.

13. Nava Flores M (2005) Análisis Armónico en la detección de Fenómenos Geomagnéticos. Unpublished dissertation, Facultad de Ingeniería, UNAM, México. 
14. Tejero-Andrade A, Cifuentes G, Chávez RE, López-González AE Delgado-Solórzano C (2015) L-and CORNER-arrays for 3D electric resistivity tomography: an alternative for geophysical surveys in urban zones. Near Surface Geophysics 13(4): 355-367.

15. Tejero A, Chávez RE, Urbieta J, Flores-Márquez EL (2002) Cavity detection in the southwestern hilly portion of Mexico City by resistivity imaging. Journal of Environmental and Engineering Geophysics 7(3): 130-139.

16. Loke M, Barker RD (1996) Practical techniques for 3D resistivity surveys and data inversion. Geophysical Prospecting 44(3): 499-523.

17. Dahlin T, Zhou B (2004) A numerical comparison of 2D resistivity imaging with ten electrode arrays. Geo physical Prospecting 52 (5): 379-398.

18. Loke MH (2000) Electrical imaging surveys for environmental and engineering studies: A practical guide to 2D and 3D surveys.

19. Argote-Espino D, Tejero-Andrade A, Cifuentes-Nava G, IriartemL, Farías S, et al. (2013) 3D electricalprospection in the archaeologicalsite El Pahñu, Hidalgo State, Central Mexico. Journal of Archaeological Science 40(2): 1213-1223.

20. Loke MH, Chambers JE, Rucker DF, Kuras O, Wilkinson PB (2013) Recent developments in the direct-current geoelectrical imaging method. Journal of Applied Geophysics 95(1): 135-156.
21. Nava Flores M (2010) Modelado por métodos potenciales de estructuras salinas inferidas por sismología de reflexión. Unpublished dissertation, Facultad de Ingeniería, UNAM, México.

22. Chávez RE, Argote DL, Tejero A, Cámara ME (2010) Geophysical Study of a Pre-Hispanic Lakeshore Settlement, Chiconahuapan Lake, Mexico. Archaeological Prospection 17(1): 1-13.

23. García Cook A (1996) El desarrollo cultural prehispánico en el norte del área, intento de una secuencia cultural. In: García Cook A, Merino B, Mirambell L, (Eds), Antología de TlaxcalaI, INAH, Mexico, pp. 247-254.

24. García Cook A (1997) The historical importance of Tlaxcala in the cultural development of the central highlands. In: García Cook A, Merino B, Mirambell L, (Eds), Antología de Tlaxcala III, INAH, Mexico, pp. 327-381.

25. INEGI, Instituto Nacional de Estadística y Geografía (2009) Prontuario de información geográfica municipal de los estados Unidos Mexicanos, Altzayanca, Tlaxcala. Clave geoestadística 29004. Instituto Nacional de Estadística y Geografía, Mexico.

26. Nabighian MN (1972) The Analitic signals of two dimensional magnetic bodies with polygona cross-section: its properties and use for automated anomaly interpretation. Geophysics 37(3): 507-517.

\section{Your next submission with Juniper Publishers will reach you the below assets}

- Quality Editorial service

- Swift Peer Review

- Reprints availability

- E-prints Service

- Manuscript Podcast for convenient understanding

- Global attainment for your research

- Manuscript accessibility in different formats

( Pdf, E-pub, Full Text, Audio)

- Unceasing customer service

Track the below URL for one-step submission https://juniperpublishers.com/online-submission.php 